\title{
Aprender e ensinar, algumas reflexões sobre arqueologias indígenas
}

\author{
Camila Pereira Jácome*
}

JÁCOME, C. P. Aprender e ensinar, algumas reflexões sobre arqueologias indigenas. R. Museu Arq. Etn. 35: 14-35, 2020.

Resumo: A arqueologia indígena é muito mais lida e praticada no plural do que no singular, tanto no que tange a suas práticas e sujeitos como no seu desenrolar teórico. Nesta apresentação farei algumas reflexões sobre a pluralidade deste termo a partir de duas experiências pessoais de pesquisa. A primeira, de uma pesquisa que realizei no mestrado e doutorado na região do rio Trombetas (PA), território tradicional de muitos povos, incluindo os Wai Wai. E a segunda, a partir da minha prática como professora de estudantes indígenas de arqueologia e antropologia na Universidade Federal do Oeste do Pará (Ufopa).

Palavras-chave: Arqueologias indígenas; Amazônia; Paisagem; Cerâmica; Educação superior indígena.

\section{Introdução}

Teste artigo farei algumas reflexões, 1 a partir de um trecho da minha trajetória na arqueologia, que envolvem experiências sobre arqueologias indígenas ou arqueologias indigenamente orientadas. Faço a primeira dessas reflexões tendo em vista algumas questões que apontei em minha tese de doutorado (Jácome 2017), pesquisa feita por uma mulher branca, arqueóloga, em território tradicional de muitos povos indígenas, a partir de um projeto de pesquisa ${ }^{1}$ pensado

\footnotetext{
* Professora Adjunta do Programa de Antropologia e Arqueologia da Universidade Federal do Oeste do Pará (PAA-UFOPA). <camilajacome88@gmail.com>

1 Este trabalho fez parte do Projeto Norte-Amazônico, coordenado pelos professores Ruben Caixeta de Queiroz e André Prous, e contou com etnólogos e arqueólogos etnólogos da Universidade Federal de Minas Gerais (UFMG). Ao longo do projeto foi feita identificação, registro e escavação de sítios arqueológicos em aldeias e outros lugares, nos rios Trombetas, Mapuera e Cachorro.
}

inicialmente por meio de questões acadêmicas e científicas, postas para e por aqueles e aquelas que trabalham na região Norte da Amazônia. Portanto, não se trata de uma arqueologia indígena, mas, a despeito disso, considero que em seu percurso a pesquisa foi muito afetada - no sentido de afecção (Favret-Saada 1990, 2005) -, por palavras, percepções e traduções indígenas. A segunda reflexão à qual me dedico ocorre a partir das arqueologias feita por jovens estudantes e pesquisadores indígenas da Universidade Federal do Oeste do Pará (Ufopa), onde sou professora. Essa experiência tem mostrado como o pensamento e as propostas de pesquisa desses jovens têm grande potencial para impactar não somente enquanto experiências de arqueologia indígena, mas também a arqueologia brasileira de modo mais amplo. Acredito que essas duas reflexões se interconectam, como uma forma de pensar tanto a arqueologia indígena quanto a própria arqueologia. 
As transformações teóricas da arqueologia praticamente nos obrigaram a desenvolver práticas arqueológicas inclusivas e descoloniais, especialmente, quando feitas em contextos comunitários indígenas (Smith \& Wobst 2005). Paralelamente a estas críticas teóricas, há o movimento das arqueologias indígenas, ou seja, pesquisas conduzidas por grupos ou pessoas de culturas nativas. As arqueólogas Cree e Stoney Tara Million (2005) apontam que a arqueologia indígena poderia ser praticada e teorizada por não indígenas, mas somente em projetos que desde sua concepção fossem elaborados por efetiva e profunda colaboração entre "ocidentais" e indígenas.

As arqueologias indígenas sem dúvida devem muito de sua visibilidade internacional ao engajamento dos povos nativos norteamericanos, em especial aqueles que vivem nos EUA, e aos grupos nativos da Austrália (Anyon 1991; Smith \& Burke 2007). Podemos remontar seus primórdios à aprovação do congresso norte-americano do Nagpra (Native American Graves Protection and Repatriation Act), demanda surgida da insatisfação desses povos com a ação dos arqueólogos, em especial em relação aos enterramentos funerários (Anyon 1991). Por conta disso, atualmente muitas pesquisas arqueológicas têm passado pelo crivo dessas comunidades.

$\mathrm{O}$ ativismo indígena do século $\mathrm{XX}$ tem utilizado diversas estratégias de proteção ao patrimônio, como a musealização feita a partir de suas próprias concepções, o estabelecimento de conselhos indígenas para dialogar com as instituições ocidentais e as leis aprovadas de proteção ao patrimônio nativo. A arqueologia é, portanto, mais uma ação dentre as várias estratégias utilizadas pelos indígenas para proteger seu patrimônio. A importância que os indigenas atribuem aos sítios e materiais arqueológicos é também uma forma de comprovar a ocupação ininterrupta de terras colonizadas e de controle desses bens.

Um ponto comum que se pode ressaltar na diversidade (metodológicas e interpretativas) das arqueologias indigenas (Smith \& Wobst 2005) é que, para a maioria delas, a arqueologia em si é apenas uma parte dos recursos culturais
(Anyon 1991). Os objetos e sítios estão inseridos em seu contexto tradicional, espiritual e histórico, o que altera completamente os direcionamentos das pesquisas e gestão do patrimônio. Se, para os ocidentais, os moldes de gestão do patrimônio público baseiam-se na ideia de confiança pública e compartilhamento, para o paradigma indígena esse patrimônio tem uma história viva (Lawson 1997; Smith \& Burke 2007; Watkins 2005).

Cristóbal Gnecco e Patrícia Ayalla, na introdução do livro Pueblos indígenas y arqueología en América Latina (2010), consideram que atualmente podemos resumir de três modos a relação da arqueologia com as demandas e as arqueologias indígenas. $\mathrm{O}$ primeiro seria o modo dos pesquisadores preocupados com a irrupção do ativismo indígena e como isso afetará a arqueologia. Um segundo viria de arqueólogos mais otimistas que acreditam na possibilidade de uma convivência pacífica entre os dois discursos. Mas é na terceira via, creio, que Gneco e Ayalla se incluem, visando traçar estratégias de participação efetiva e pontes de entendimento interdiscursivo (2010: 24-25). Os autores também apontam que, embora certas pesquisas reconheçam a continuidade histórica entre grupos indigenas do presente com alguns contextos arqueológicos, é raro que elas levem os indígenas para dentro de suas "indagaciones históricas (como interlocutores o como actores empoderados) o para acompañar sus interpretaciones de la historia sino para obtener pistas interpretativas, sobre todo de los mitos" (Gnecco \& Ayalla 2010: 30).

Os movimentos sociais indígenas geraram empoderamento, dinamizando as lutas contra as políticas de Estado, reclamando o direito à diferença e autonomia. $\mathrm{O}$ desafio atual da arqueologia é sair do seu monopólio narrativo de contadores oficiais da história pré-colonial para assumir um papel de intermediação, agora que os indígenas demandam sua própria representação. Gnecco \& Ayalla (2010) afirmam que nem sempre essas autorrepresentações históricas vão recorrer à arqueologia, visto que é mais frequente o uso de narrativas próprias (chamadas de mitos, na denominação ocidental). Todavia, nas últimas décadas, 
algumas comunidades indígenas têm procurado na arqueologia um caminho de expressão política e cultural, seja aproximando-se de arqueólogos não indígenas, seja formando seus próprios pesquisadores.

Interessa, nesse enfrentamento de narrativas da "ciencia de los arqueólogos contra la sensibilidad de los indígenas; el racionalismo del conocimiento experto contra la irracionalidad del saber nativo" (Gnecco \& Ayalla 2010: 30), que não se trata de formas de relações excludentes. O desafio disciplinar é tirar a arqueologia do papel da não representatividade indígena (intencional ou não), que deixa de lado a sua responsabilidade com as comunidades, seja por isolamento ou oportunismo acadêmico. O momento agora é outro: é preciso expor a natureza filosófica de nossa disciplina. Ressalto que é no encontro, desencontro e no confronto com o outro que nos reconhecemos melhor. O silêncio, seja o científico ou do cinismo multicultural é colonizador.

Desta forma, procurei tratar e desenvolver minha pesquisa considerando essa tentativa de elaborar uma arqueologia que fosse ao encontrasse dos povos indígenas do Rio Trombetas e seus afluentes, com seus olhares e interpretações sobre aquilo que nós chamamos de cerâmicas e paisagens arqueológicas (Jácome 2017).

\section{A trajetória na pesquisa}

A pesquisa que realizei na bacia do rio Trombetas teve início em 2010 e término em 2017 (Jácome 2017). Dos Pooco aos Wai: mudanças e permanências nas ocupações ceramistas no Altomédio Trombetas no Norte Amazônico brasileiro foi como intitulei primeiramente minha proposta de pesquisa de doutorado. $\mathrm{O}$ foco era estudar as ocupações ceramistas do alto-médio rio Trombetas sob a perspectiva das mudanças e permanências culturais dos grupos ceramistas da região. A partir do levantamento feito no mestrado (Jácome 2011), estava bem evidente que o passado pré-colonial da região do rio Trombetas era ainda pouco conhecido do ponto de vista arqueológico, tendo em vista a escassez de pesquisas neste extenso território. A sequência cronológica estabelecida até então era baseada, principalmente, nas pesquisas de sítios da confluência do rio Trombetas e do rio Nhamundá. A sequência cronológica identificava quatro tipos de cerâmica: Pocó, Konduri, globular e cerâmica "espinha de peixe" (Hilbert 1955; Hilbert \& Hilbert 1980)². As datações mais antigas relativas à ocupação Pocó indicam aproximadamente o século II a.C. e as últimas datações Konduri são do século XV (Guapindaia 2008; Guapindaia \& Lopes 2011).

O objetivo central do projeto de tese era estabelecer uma cronologia regional para a região do alto Trombetas e seus afluentes pouco estudados, como Mapuera e Cachorro, e a partir daí verificar a possível relação com os sítios do baixo Trombetas e do Nhamundá. Outra questão que propus inicialmente pretendia verificar se haveria uma continuidade entre os ceramistas Konduri e os grupos Karib históricos e etnográficos, considerando que a relação entre os grupos históricos e os atuais já foi estabelecida por outros trabalhos (Gallois 2005; Howard 2001; Queiroz 2008). O projeto inicial sofreu algumas mudanças significativas, dentre as quais a primeira foi o título. Quando comecei a pesquisa de doutorado o título do projeto era Dos Pooco aos Wai. A palavra pooco, (a aproximação fonética em português seria fotxó) que na língua Wai significa avô ou qualquer homem idoso, fazia também alusão à cerâmica Pocó, considerada a mais antiga do baixo Amazonas (Guapindaia 2008; Hilbert \& Hilbert 1980).

A ordem dos nomes evidenciava minha busca por construir uma história de longa duração da região do rio Trombetas/Mapuera, desde os primeiros registros arqueológicos até as ocupações atuais dos grupos ditos Wai Wai. Ou seja, meu ponto de partida era a arqueologia e sua busca por uma "origem". No entanto, no decorrer da pesquisa essa questão da ordem cronológica e das relações entre passado arqueológico e presente etnográfico foram

2 Os vestígios do período pré-cerâmico não foram mencionados por nenhum autor que trabalhou na região (Guapindaia 2008; Hilbert 1955). 
sendo reposicionadas. A questão temporal da qual eu estava tratando inicialmente dizia respeito ao tempo linear ocidental, dos Pooco (passado) para os Wai Wai (presente). Contudo, ficou cada vez mais forte a ideia de que a temporalidade dos coletivos que estão hoje sobre os sítios arqueológicos do rio Mapuera estava transformando o que eu entendia sobre esses lugares e objetos. Portanto, a inversão do título, para "dos Wai Wai ao Pooco", no meu entender, não é uma formalidade de escrita, mas sim uma mudança profunda com repercussões significativas no modo como interpretei cerâmicas e sítios arqueológicos.

Também ocorreram outras mudanças que considero menos drásticas. A primeira delas foi o recorte geográfico. $\mathrm{O}$ projeto restringiu-se aos sítios do rio Mapuera, apesar da pequena incursão aos rios Cachorro e Erepecuru. A prospecção consistiu no levantamento de locais (atualmente aldeias e roçados, alguns recém-abandonados) que são sítios arqueológicos. A prospecção foi definida pelos diálogos e negociações entre a equipe de arqueologia e os interesses dos povos do Mapuera. Após os trabalhos de campo, a compreensão da relação dos sítios e de sua inserção na paisagem foi sendo amadurecida e, mais do que isso, tornou-se evidente o encontro da paisagem arqueológica com a paisagem dos povos que habitam hoje o Mapuera. Acredito que esse investimento no diálogo com os grupos contemporâneos sobre as paisagens e a coincidência regular dos assentamentos atuais e dos pré-coloniais são muito importantes. Trata-se da materialização de duas opções que convergem no presente, que refletem estruturas materiais e imateriais que se desenvolveram no tempo de longa duração. Nesse sentido, optei por refletir sobre a noção de tempo dos grupos indígenas e não investi nas análises documentais históricas, como propus originalmente.

Sobre a questão das cerâmicas, também identificamos (Glória 2017; Jácome 2017) que as definições fechadas de cerâmica

Konduri, Tarumã, Wai Wai e até Koriabo (Boomert 1981, 2004; Evans \& Meggers 1955, 1960; Hilbert 1955; Meggers 2010) não estavam de acordo com os resultados de nossas análises. Nos deparamos com contextos arqueológicos bastante alterados pela contínua ocupação, mas também com contextos tecnológicos "misturados", o que nos evocou a questão das "misturas" (Queiroz \& Girardi 2012) entre os diferentes grupos que, como veremos adiante, constitui uma das principais características sociológicas dos povos guianenses e do rio Trombetas. Em relação à cerâmica, além de uma tradicional análise tecnológica, também investi em pesquisar indícios da relação de algumas peças com a prática xamânica.

Neste artigo apresento dois exemplos (Jácome, 2017): um sobre a relação entre a paisagem atual dos povos indígenas e a paisagem arqueológica no rio Mapuera; e outro sobre a relação de fragmentos cerâmicos arqueológicos (especificamente apliques zoomórficos de estilo Konduri) e o xamanismo. Antes, porém, faço uma contextualização sobre a geografia e os povos que vivem na região do Trombetas.

\section{Contextualização}

A bacia do rio Trombetas, afluente do Amazonas que deságua em sua margem esquerda, próximo à cidade de Oriximiná/PA, tem seus formadores no Escudo das Guianas.

Entre os afluentes mais importantes do Trombetas, pelo lado direito, estão o Mapuera e o Cachorro, e pelo lado esquerdo o Erepecuru. A topografia desta região é marcada por vários desníveis, que criam trechos de cachoeiras e corredeiras ao longo dos rios. Em suas margens é comum ver elevações com afloramentos rochosos, algumas das quais apresentam pinturas rupestres. 


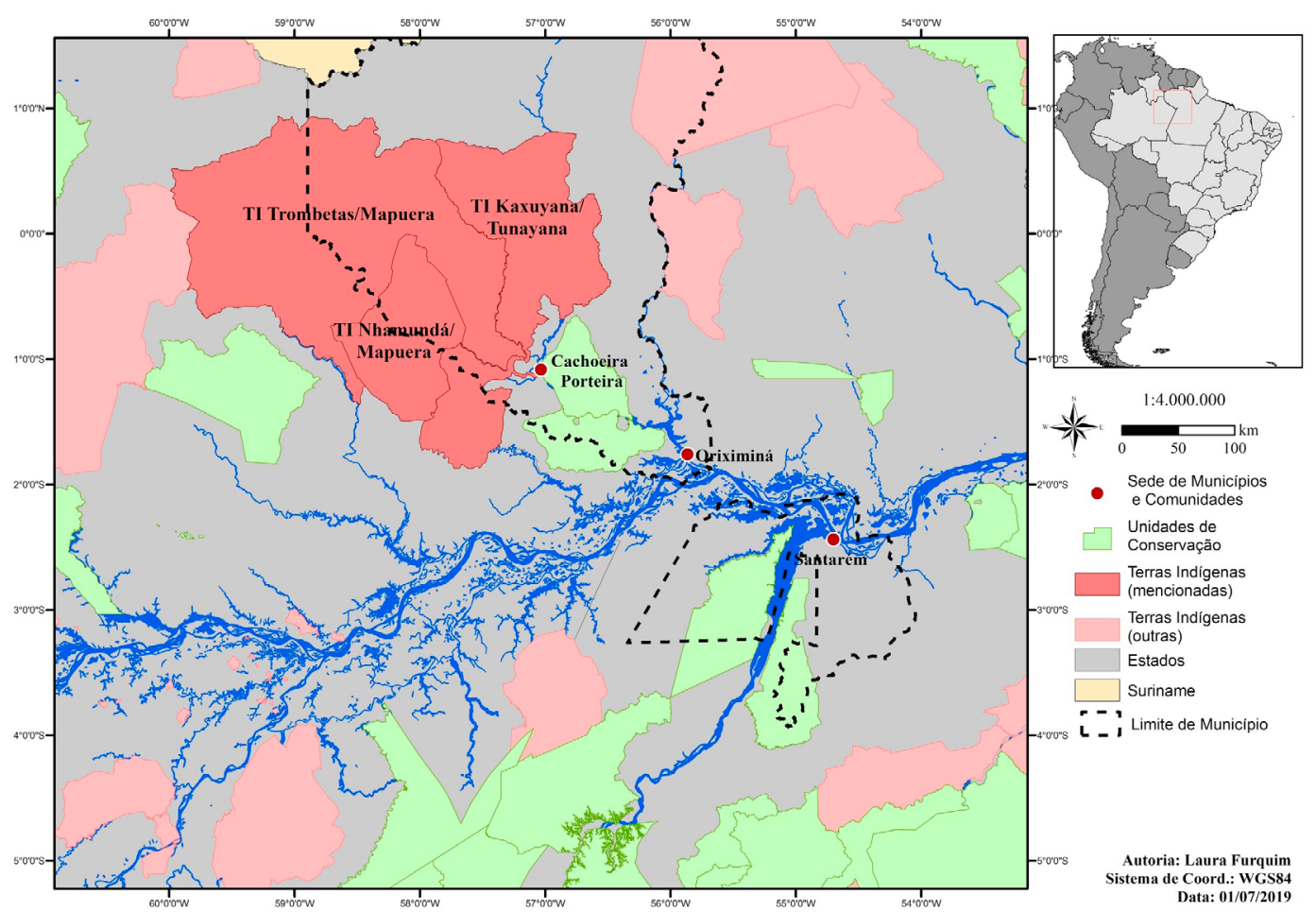

Fig. 1. Mapa de localização das terras indígenas mencionadas.

Fonte: Laura Furquim (2019).

A respeito das populações que habitaram o Trombetas, as primeiras informações históricas, datadas dos séculos XVI e XVII (Acuña 1941; Bettendorff 2010; Heriarte 1874), mencionam grupos que viviam em grandes aldeias onde era fabricada uma "fina louça", posteriormente batizada de Konduri por Curt Nimuendaju (2004). Já no século XVIII, o efeito devastador do contato decorrente de epidemias e guerras levou os grupos remanescentes a fugirem e se isolarem nas cabeceiras do Trombetas e Mapuera (Porro 2008). Esse contexto de epidemias, guerras e fugas se prolonga até a segunda metade do século XX. A partir daí missões religiosas passam a atuar na região; missionários católicos retiraram grupos do Cachorro e do Trombetas, que foram levados para a Missão Tiriyó, na serra do Tumucumaque (Frikel 1958, 1970; Howard 2001; Queiroz 2008). Alguns grupos do Mapuera subiram para a divisa com a Guiana
Inglesa, onde estabeleceram contato com missões evangélicas norte-americanas (Fock 1963; Howard 2001).

A conversão dos primeiros Wai Wai ao evangelismo levou ao abandono do xamanismo como prática (Howard 2001; Queiróz 1999; Valentino 2010). Além disso, também foi importante a intensificação do contato com outros grupos isolados, pois os Wai Wai iam em busca deles para trazê-los às aldeias-missões. Essa proximidade permitiu que grupos distintos fossem alcunhados como Wai Wai. Ou seja, por detrás desse etnômio se esconde uma enorme diversidade de grupos, ou yanas, sufixo que significa gente ou povo. Os grupos que vivem hoje nas comunidades Wai Wai falam uma mesma língua, mas seus dialetos maternos são variados, a maioria da família Karib, como: Parukoto, Tarumã, Xerew, Katuena, Tunayana, Karapawyana, Mawayana, dentre outros. Possivelmente a língua Mawayana tem origem 
Arawak (Howard 2001; Queiroz 2008), mas, passou por um processo de "karebização". Esses grupos vivem hoje nas terras indígenas: Trombetas Mapuera e Katxuyana Tunayana (Queiroz \& Girardi 2012).

\section{Paisagens}

Passo então ao primeiro exemplo sobre a relação entre paisagens históricas e arqueológicas. Opto por usar o termo história no lugar de mitos devido às reflexões de Vanessa Watts-Powless (2017), socióloga Moahawk e Anishnaabe. A autora indica que os entendimentos e narrativas de mundo dos indígenas são

considerados modos alternativos de compreensão e interpretação, ao invés de eventos 'reais'. Colonização não é um ataque apenas às pessoas e aos territórios, mais que isso, esse ataque é consumado em parte através de uma ignorante e deturpação das cosmologias indígenas (2017: 253).

Esse entendimento vai ao encontro do que os jovens acadêmicos Wai Wai da Ufopa têm proposto: o que nós ocidentais chamamos de mito, para seu povo são histórias. Jaime Xamen Wai Wai, primeiro arqueólogo indígena formado pela Ufopa, e muito provavelmente o primeiro no Brasil, em diversas ocasiões menciona quão fantástica parece ser a narrativa da evolução humana, que para nós tem um caráter de verdade científica ${ }^{3}$. Portanto, considerando que estou tratando de lugares

3 Vanessa Watts-Powless (2017) analisa a história da Mulher do Céu, que narra a origem da humanidade e da terra para os Moahawk e Anishnaabe, além da narrativa bíblica de Eva e do paraíso perdido. Nesta análise ela demonstra como a narrativa bíblica estabelece as relações entre humanos e outras espécies como perniciosas, assim como a ação da mulher leva à condenação de toda a humanidade. Por outro lado, a história da Mulher do Céu mostra diálogo e negociação entre a mulher e outros seres também dotados de espíritos (animais, terra e plantas), além de colocá-la em lugar central, vinculando-a à terra em uma relação de sacralidade. apresentados pelos Wai Wai, vou me referir a estas paisagens como históricas.

Primeiramente apresento a história de Petaru, cobra grande, que habitou as paragens do alto Mapuera. Essa história foi relatada a Caixeta de Queiroz (2015: 119-121) por Cekma, em 2000, na aldeia Mapuera.
A história diz o seguinte, havia um homem que era dono de uma cobra grande, que lhe deu o bonito nome de Petaru, ele a criava como um animal de estimação, lhe fez um cercado na beira do rio, e todo dia a alimentava com carne de cotia (akri), cotia pequena (paski) e pakria (caititu). Como sempre era alimentada, a cobra foi ficando mansa, igual cachorro, lam/bia a esposa do seu dono, e não se comportava como cobra grande, mas parecia gente de verdade, em sua mansidão. Petaru cresceu muito, pois era sempre bem alimentada. Um dia, seu dono foi caçar. Os meninos da aldeia logo vieram the cochichar, "seu dono disse que ia caçar cotia pequena (paski), mas na verdade ele foi atrás de cotia (pakria)". Petaru ficou muito brava com seu dono e queria lhe matar. Quando seu dono retornou e lhe trouxe cotia pequena, ela não o respondeu, como sempre fazia ao seu chamado. O homem chamou sua mulher e questionou sobre o comportamento de Petaru, ela foi ver então a cobra. Chegando lá, a cobra quebrou seu cercado e engoliu a mulher do seu dono. A água ficou borbulhando. Todos se questionaram o porquê de Petaru ter feito isso e resolveram ir atrás dela, seguindo o conselho do pajé Xurupana. Então todos viraram ariranha (wayawaya) e juntos foram descendo o rio procurar Petaru. Tiveram notícia que ela estava no poço Wamá, que fica perto da Cachoeira de Bateria (Uakri, no rio Mapuera). Petaru achando que estava bem escondida ficou lá. Encontraram Petaru dentro do poço escondida atrás das cobras pequenas. $\mathrm{O}$ grupo de ariranhas resolveu voltar para sua aldeia, Kuumutîrî, para decidirem o que fazer, e pensaram com ajuda do seu dono e do pajé, que a melhor solução era jogar timbó na água (retirado 
do braço de uma mulher velha). A velha juntamente com Kworo [arara vermelha], Kwayari [arara vermelha de asas azuis], Xaapi [arara de cor azul e amarela], Yakwe [tucano de peito branco], Peeu [galo das rochas], Worohku [pássaro de tamanho médio e avermelhado] baixaram para o poço Wamná. Quando a velha pôs seus braços na água, apareceu uma cobra morta, apareceram outras pequenas, até que Petaru apareceu, aí flecharam seu corpo. Puxaram-na para pedra e todos os povos que vieram junto com a velha cortaram Petaru. Como ela era muito comprida foi cortada em muitos pedaços. Onde ela foi cortada se chama Okoimokoto [pedaço da cobra-grande]. $\mathrm{O}$ lugar ficou cheio de sangue que as aves usaram para se pintar. O Kwayaryana [povo arara vermelha de asas azuis] se pintou só um pouco, por isso não ficou bem vermelho. Já o Kworoyana [povo arara vermelha] botou muito sangue no corpo e ficou bem vermelho. Todos passarinhos chegaram, Worohku também ficou bem avermelhado. Já o Yakwe colocou só no rabo, ficou só um pouquinho vermelho. Por fim, chegou o Xaapyana [arara amarelada] e disse: "Eu quero, me dá sangue". A velha indagou-lhe: "Por que não veio antes? Está atrasado, você é preguiçoso”. Xaapi botou só um pouco de sangue e, por isso, ela é amarelada só no peito. A velha disse: "Todo mundo já botou sangue no corpo, vamos voltar para a aldeia”. Então começou a longa viagem de volta. Durante o retorno choveu, Kwayari foi logo para a casa dele, o Yakwe se molhou um pouco e a água lavou suas costas. Xaapi, que era preguiçosa, correu para sua casa, mas a chuva limpou quase todo seu corpo e, por isso, ela é só amarelada. Depois da chuva, voltaram para a aldeia Kuumutîîi [o lugar da bacaba], lá onde moravam os Kworoyana, os Kwayaryana, lá onde havia muita bacaba.

\section{Ruben Caixeta de Queiroz, ao comentar o} mito de Petaru, diz que a narrativa remete ao universo dos relatos indígenas sobre a cobra grande (anaconda, ou sucuri), muito frequente em vários outros povos e contextos etnográficos.
Segundo ele, essa história tem relação com o valor estético e diferenciação das pessoas. A sucuri é um animal considerado perigoso, mas ao mesmo tempo belo, pois tem a pele ornada de grafismos próprios e o poder contínuo de transformação e rejuvenescimento, já que pode trocar de pele. No caso da história de Petaru, o tema central é a origem da cor dos pássaros e a diversidade dos grupos humanos, pois, como vimos, as aves também recebem o sufixo yana (povo) e Kworoyana significa "povo arara vermelha" $($ kworo $=$ arara vermelha; $y a n a=$ povo). Esses povos-pássaros se diferenciam justamente pela quantidade de sangue de Petaru com que se pintam. Tal diversidade surge justamente da fragmentação de Petaru.

O que nos interessa para a análise é a relação com a paisagem do rio Mapuera, onde hoje se encontra a maioria das aldeias do povo Wai Wai na terra indígena Trombetas-Mapuera. Petaru e seu dono moravam no alto Mapuera, lugar tradicional de antigas aldeias Wai Wai e de outros povos. Na história de Petaru, as pessoas transformadas em ariranha pelo pajé saem de uma aldeia chamada Kumuutîrî para achar a cobra grande escondida. Em 2011 saímos de canoa da aldeia mais a montante do rio Mapuera, numa expedição por aldeias antigas e sítios de arte rupestre que foi guiada pelo pai do cacique dessa aldeia, o ancião Poroswe. Ele nos levou a um local denominado Kurumîtî, no alto Mapuera. Apesar da pequena diferença gráfica, parece se tratar do mesmo lugar, onde Petaru foi criada e fugiu. Esse local nos foi apontado por Poroswe como uma aldeia muito grande onde ocorriam muitas festas (Jácome 2017). O local é um sítio arqueológico multicomponencial, com cerâmica e rochedos com gravuras rupestres. Um dos rochedos foi gravado com o grafismo voltado para a terra firme, onde seria antiga aldeia de Kumuutîrî. Nele há um único grafismo formado por linhas retilíneas perpendiculares, que se assemelha bastante aos padrões gráficos atuais, como registrados por Denise Fajardo Grupioni (2009) para os Katxuyana e Tiryió, como sendo de parte ou do todo do corpo de cobras. Seria uma indicação da aldeia de Petaru, onde ela teria sido criada? 


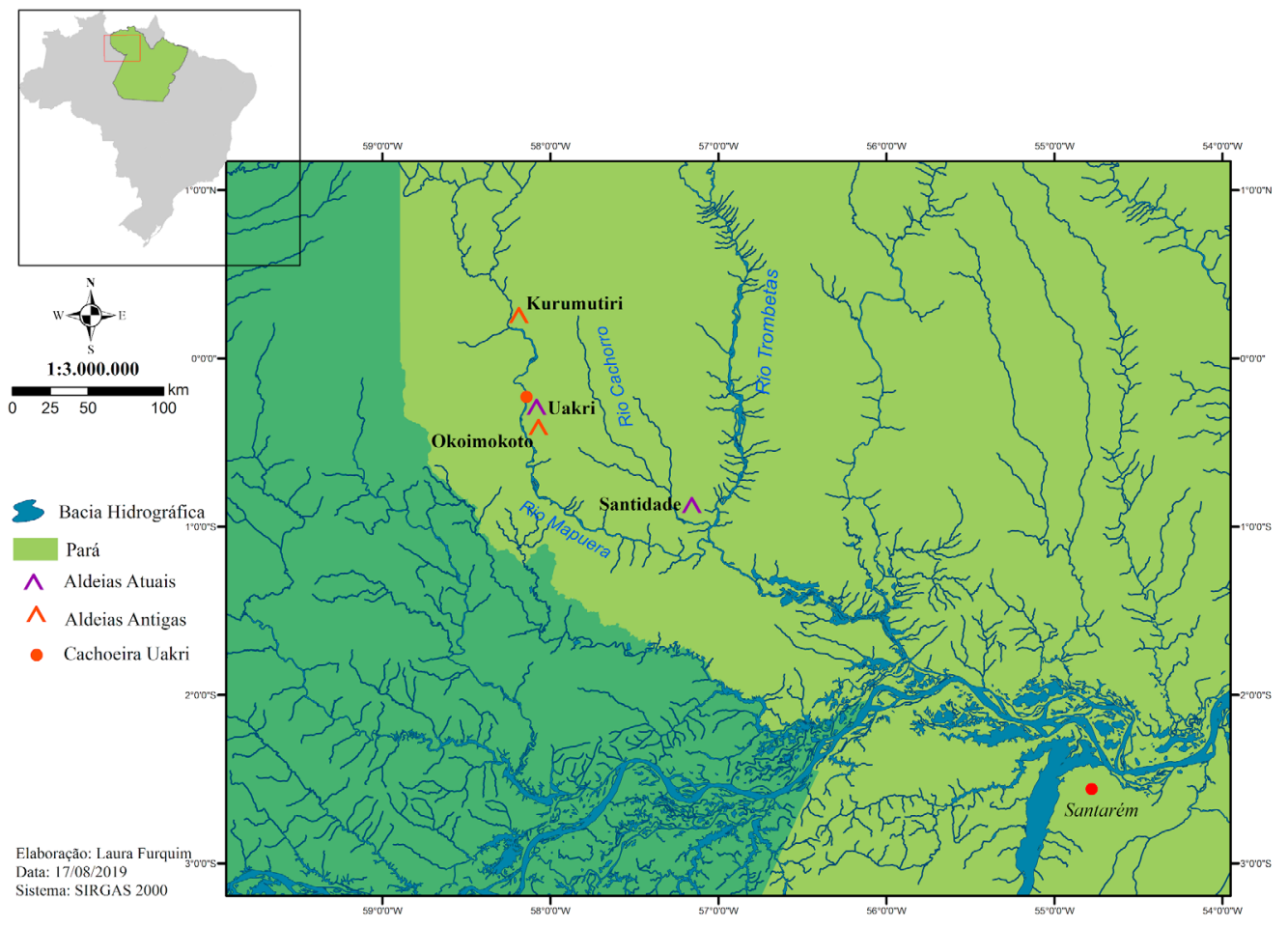

Fig. 2. Mapa com a localização das aldeias antigas, sítios arqueológicos, aldeias atuais e cachoeira.

Fonte: Laura Furquim (2019).

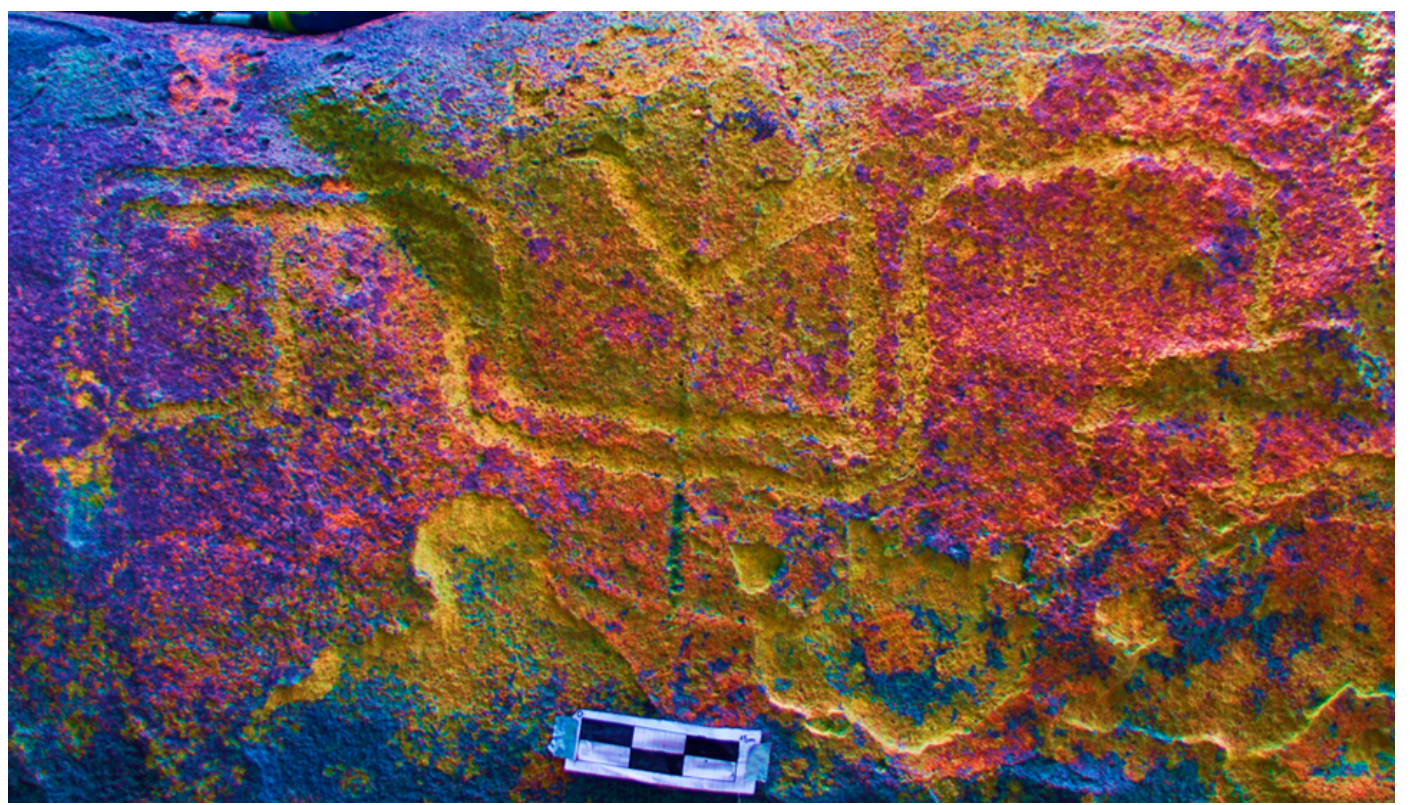

Fig. 3. Gravura em rochedo do Kurumîtîîi. A imagem recebeu tratamento cromático para realçar os contornos das linhas e facilitar a visualização do desenho.

Fonte: Fotografia e tratamento de Camila Jácome. 

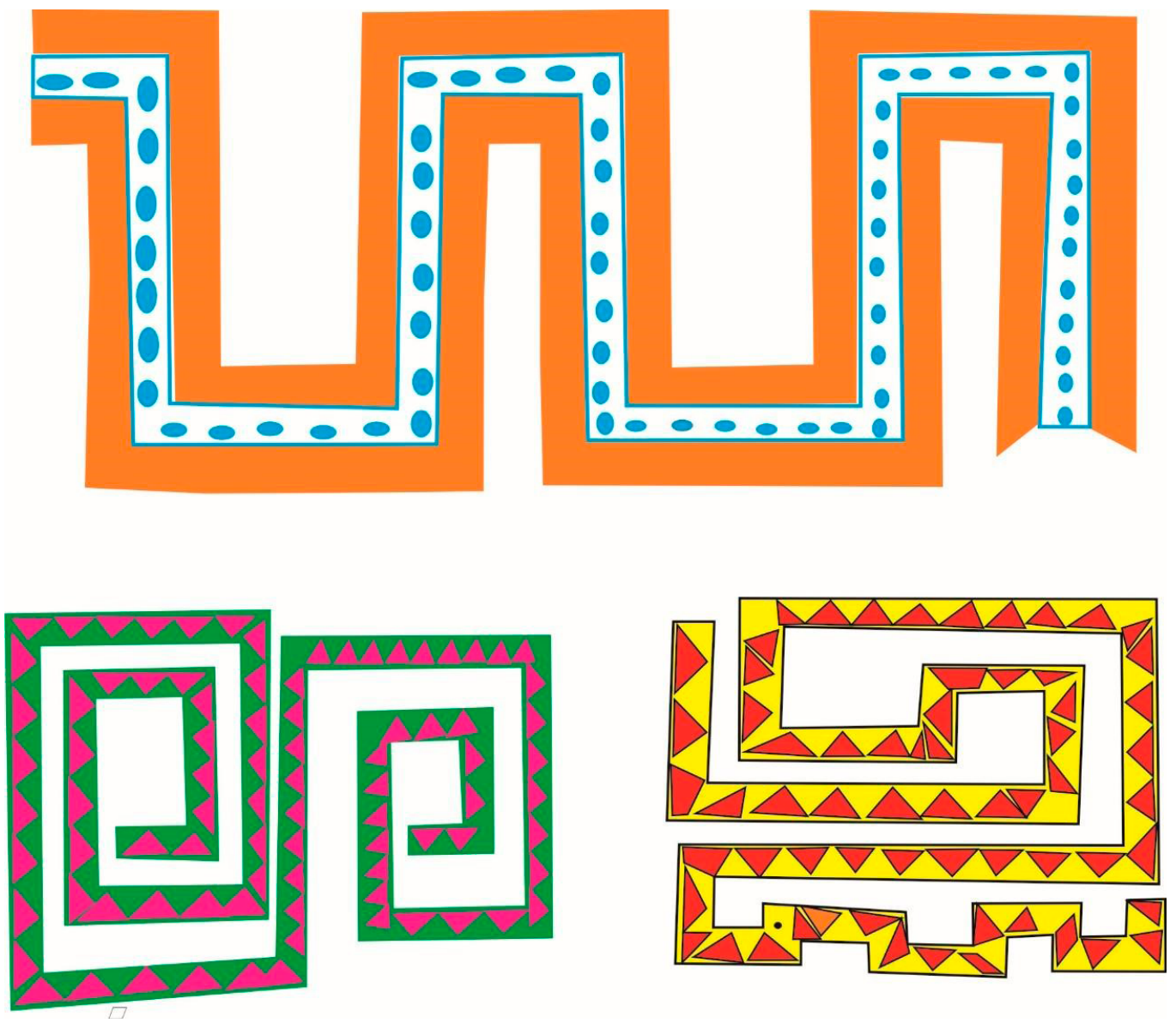

Fig. 4. Padrões gráficos compartilhados pelos Katxuyana e Tiriyó de partes e/ou do corpo inteiro da cobra. Fonte: Redesenhado por Camila Jácome a partir da publicação de Grupioni (2009).

Mais abaixo no rio Mapuera há dois outros lugares mencionados na história de Petaru. O primeiro deles foi onde Petaru teria se escondido, um poço na cachoeira de Bateria, uma das mais longas e perigosas do rio Mapuera.
Não conseguimos acessar o local do poço, pois a travessia foi difícil e seria necessário um grande desvio para chegar ao local. Mas sabemos, por referência bibliográfica (Yde 1963), que nessa cachoeira também há rochedos com grafismos rupestres. 


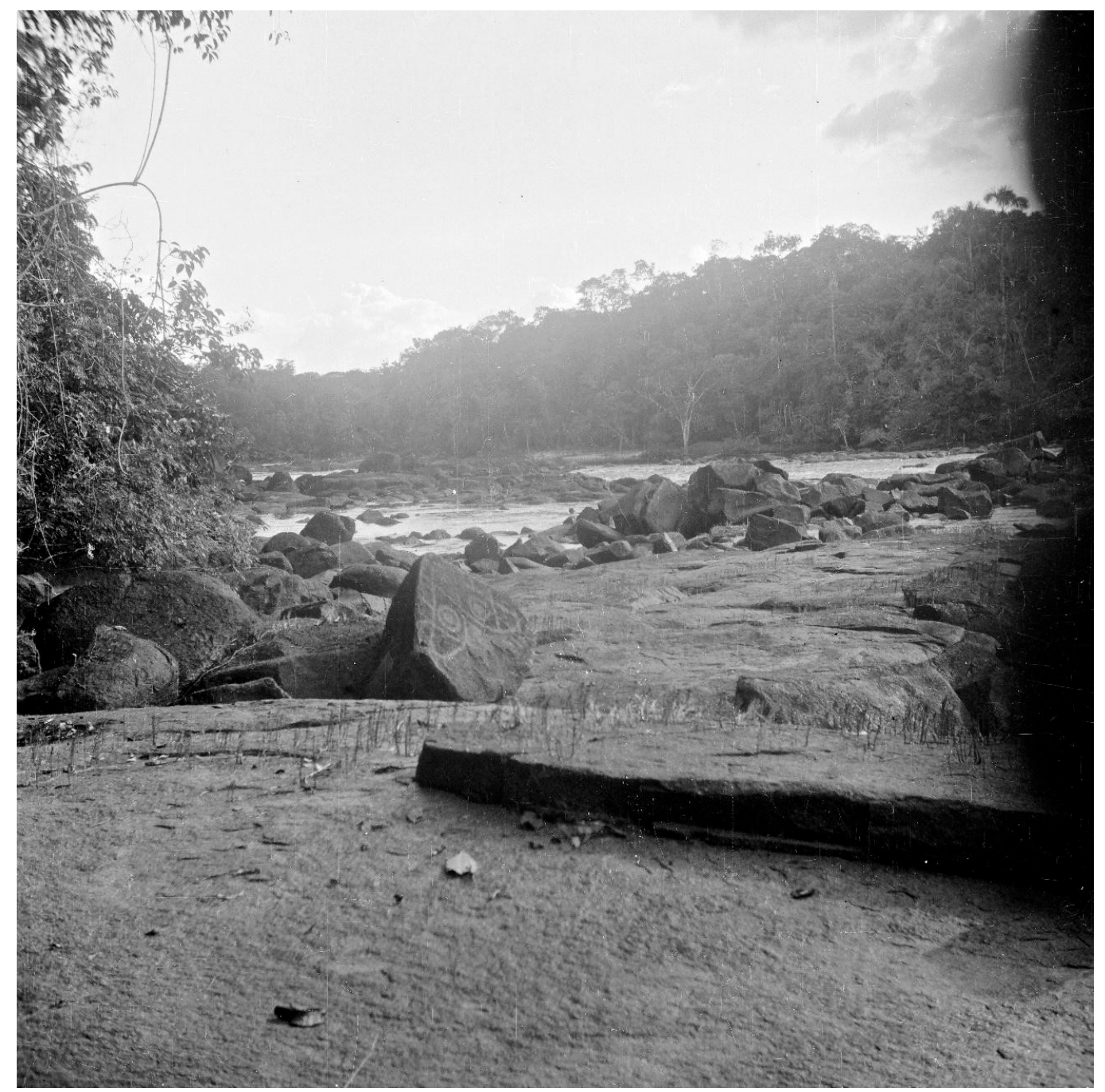

Fig. 5. Trecho da cachoeira de Bateria, no rio Mapuera, com gravura rupestre. Foto de Jens Yde, parte dos arquivos da Coleção Niels Fock, The Archive of the Indigenous Language of Latin American.

Fonte: 〈https://bit.ly/3mSTwlp>. Acesso em: 18/07/2019.

O segundo lugar é onde Petaru foi cortada, Okoimokoto, abaixo da cachoeira, em um grande afloramento rochoso no meio do rio. Um dos registros arqueológicos no afloramento é de uma bacia de polimento para confecção de artefatos polidos. Mas, de acordo com Poroswe, trata-se de uma das marcas deixadas pela faca que cortou Petaru. A morfologia da rocha também é um sinal de que o local foi palco de outra história muito importante para os Wai Wai. O rochedo apresenta concavidades e arestas, que são explicadas pela geologia como fruto de processos erosivos (eólico, pluvial). No entanto, para os Wai Wai, trata-se das pegadas de Mawari, pois a pedra ainda era mole quando ele passou por ela, de forma que ficou marcada pelos seus pés. Mawari e seu irmão Washi são os criadores do mundo e de muitos implementos tecnológicos, como o machado de pedra e a armadilha para peixe (Fock 1963). 
Aprender e ensinar, algumas reflexões sobre arqueologias indígenas R. Museu Arq. Etn., 35: 14-35, 2020.

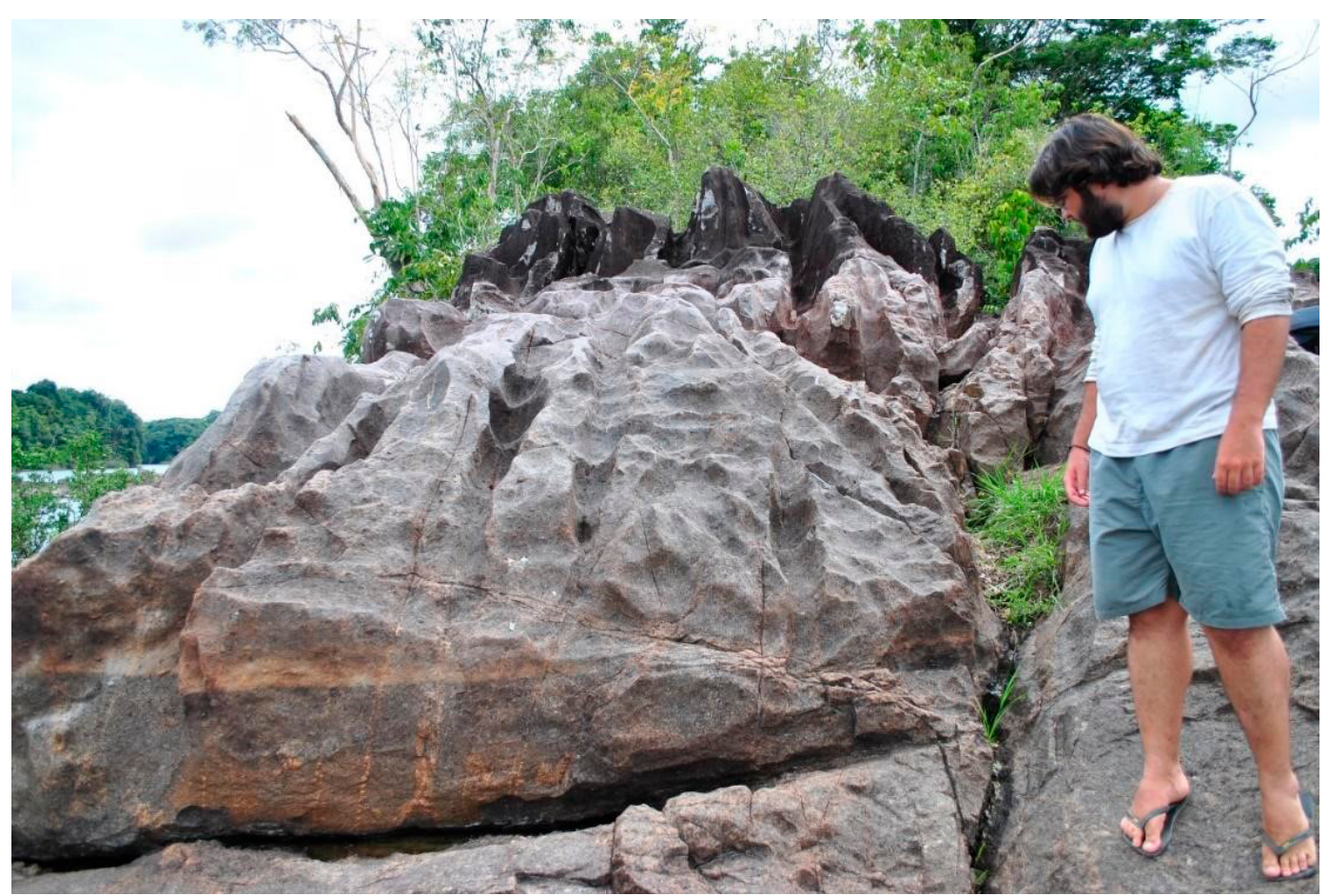

A

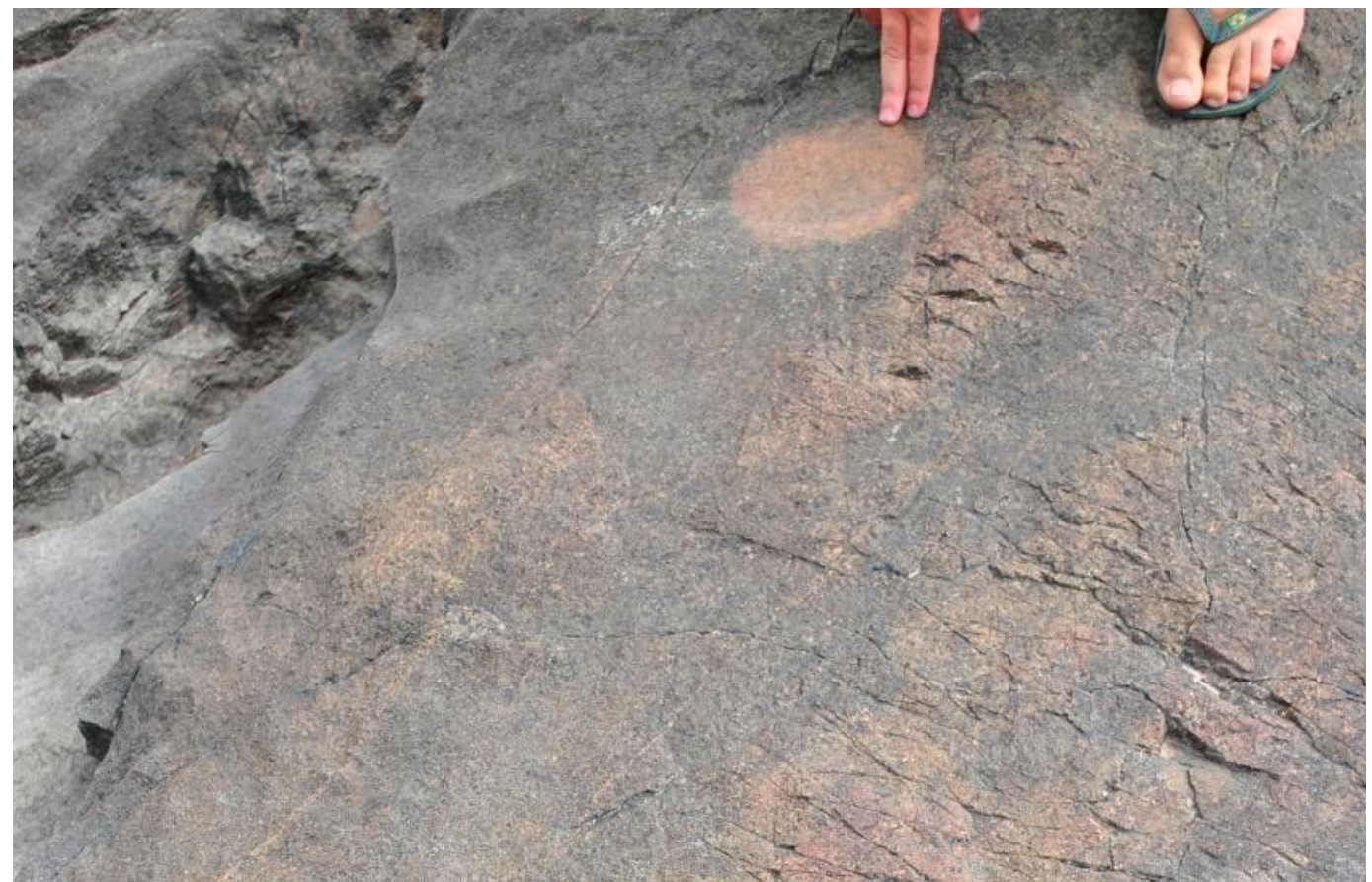

B

Fig. 6A, 6B. Localização de Okoimokoto, local onde Petaru foi morta e cortada. Na segunda foto notam-se marcas de afiadores e bacias de polimento que são também as marcas da faca que cortou o corpo da cobra grande.

Fonte: Fotografias de Camila Jácome. 
Uma questão importante a ressaltar é a forma de relatar essas histórias não fixas, pois alguns detalhes de localização ou de eventos podem ser diferentes, dependendo de quem narra a história. A história de Petaru está bem referenciada geograficamente no rio Mapuera, mas Caixeta de Queiroz mostra que, por exemplo, para Menura, que é Xerew, essa história ocorreu no alto rio Cachorro, local de onde esse grupo veio. Nota-se, portanto, que há uma relação direta desses lugares narrados na história com os sítios arqueológicos. A história de Petaru se inicia em Kuumîtîrî (ou Kurumîtîrî), em um sítio arqueológico com cerâmica e arte rupestre, e termina em Okoimokoto, um afloramento com bacias de polimento. Não acredito que isso seja mera coincidência, mas que demonstra essa relação entre a paisagem e a memória. Essa memória pode ser tanto de ordem cronológica, no sentido de rememorar lugares e aldeias onde os ancestrais viveram, quanto uma história dos tempos da indiferenciação entre humanos e animais. Este é um dos exemplos que analisei sobre a paisagem arqueológica e histórica dos povos que vivem na bacia do Trombetas (Jácome 2017). Em todos é evidente que as marcas e vestígios arqueológicos também são, para esses diversos povos indígenas, marcas do passado.

\section{Cerâmicas}

Passo ao meu segundo exemplo, sobre a relação entre cerâmica e xamanismo. Certa vez, em uma conversa despretensiosa com um dos caciques do rio Mapuera, eu mostrava fotos de apliques zoomorfos muito típicos da cerâmica Konduri. Ao ver as fotos ele nos disse que aquelas peças antigamente eram usadas nas curas feitas pelos pajés (yaskomo) e completou afirmando que se fossem mostradas para um "ex" pajé ele voltaria a sê-lo. Essa fala me intrigou muito e me fez pesquisar como a cerâmica poderia ser usada ou ser relacionada aos pajés. Para isso fui em busca dos registros etnográficos sobre o xamanismo Wai Wai (Fock 1963). Aos poucos algumas referências surgiram.

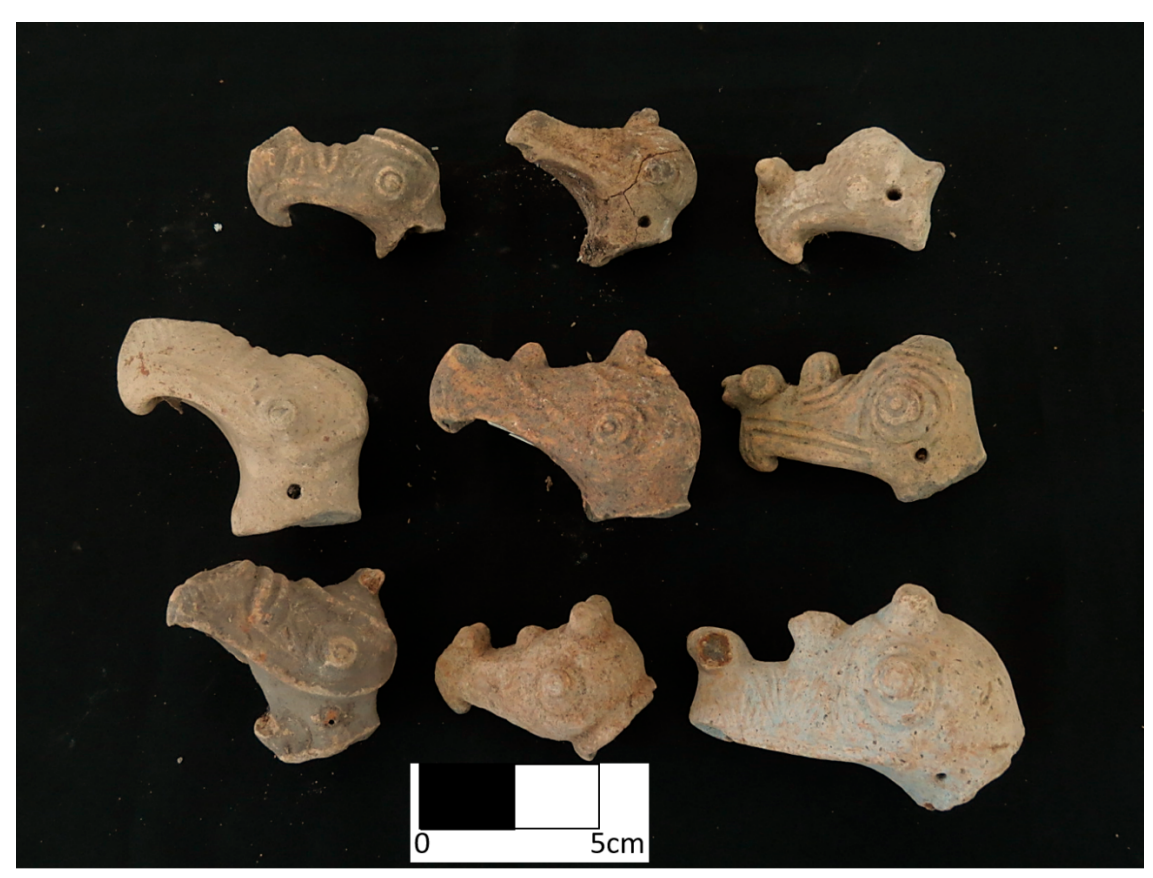

Fig. 8. Apliques de cabeça de urubu Konduri pertencentes à coleção da Casa de Cultura da Prefeitura de Oriximiná.

Fonte: Fotografia de Igor Rodrigues. 
Aprender e ensinar, algumas reflexões sobre arqueologias indígenas

R. Museu Arq. Etn., 35: 14-35, 2020.

A maioria das pessoas das aldeias do Mapuera, Cachorro e Trombetas não demonstra muito interesse em relação aos objetos arqueológicos que brotam no solo de suas aldeias, nem quanto àqueles que escavamos nos sítios arqueológicos. Talvez parte desse desinteresse venha daquilo que Maria Luisa Lucas (2014) observou nos Hixkaryana. Apesar do grande interesse e disposição em falar sobre as histórias do tempo dos antigos, há também uma certa restrição a algumas delas, histórias que têm um poder em si, que podem despertar espíritos e/ou doenças. $\mathrm{O}$ antídoto para elas e as curas feitas pelos antigos pajés hoje são raros ou inexistentes. Talvez essa interdição a respeito das histórias também possa ser estendida aos objetos achados, como as cerâmicas arqueológicas. Teriam os fragmentos Konduri algum poder ou animu quando vistos e/ou manipulados pelos xamãs?

A cerâmica arqueológica aparece novamente em relatos sobre os Katuena, fornecidos por Leonor Valentino (2010), e em outro sobre os Katxuyana, por Luisa Girardi. Ambos indicam que os fragmentos cerâmicos arqueológicos encontrados nas aldeias são cacos das panelas quebradas dos Okoymoyana, Povo Cobra Grande, cujas aldeias subaquáticas são vizinhas às terrestres dos indígenas. Os Okoimoyana antigamente eram mais próximos dos Wai Wai, e ainda existem, apesar de serem pouco vistos atualmente. O Povo Cobra Grande, como apresentou Fock (1963), são yanas espirituais, mas são vistos como humanos quando emergem à superfície.

Apesar do aparente desinteresse que as pessoas demonstravam pelos objetos arqueológicos, em quase todas as aldeias que visitamos pelo menos uma família mantinha uma pequena coleção de peças arqueológicas, em geral composta por adornos zoomorfos Konduri, algumas vasilhas pequenas inteiras e lâminas de machado. A Figura 9 ilustra uma dessas coleções, com diversos apliques e apêndices zoomórficos na aldeia Santidade do rio Cachorro. Nota-se que em um deles está transpassado um fio, como um colar, que foi passado pelo furo da base da cabeça do urubu. Essa mesma peça foi pintada recentemente em preto, vermelho e amarelo, ressaltando os detalhes que evocam a espécie desse apêndice, a cabeça do uruburei. Poderíamos ler essa peça pela chave da "reapropriação", da "ressignificação", ou considerar como uma simples curiosidade. No entanto, outros elementos continuaram nos aproximando de uma relação desses "pingentes" Konduri com o xamanismo.

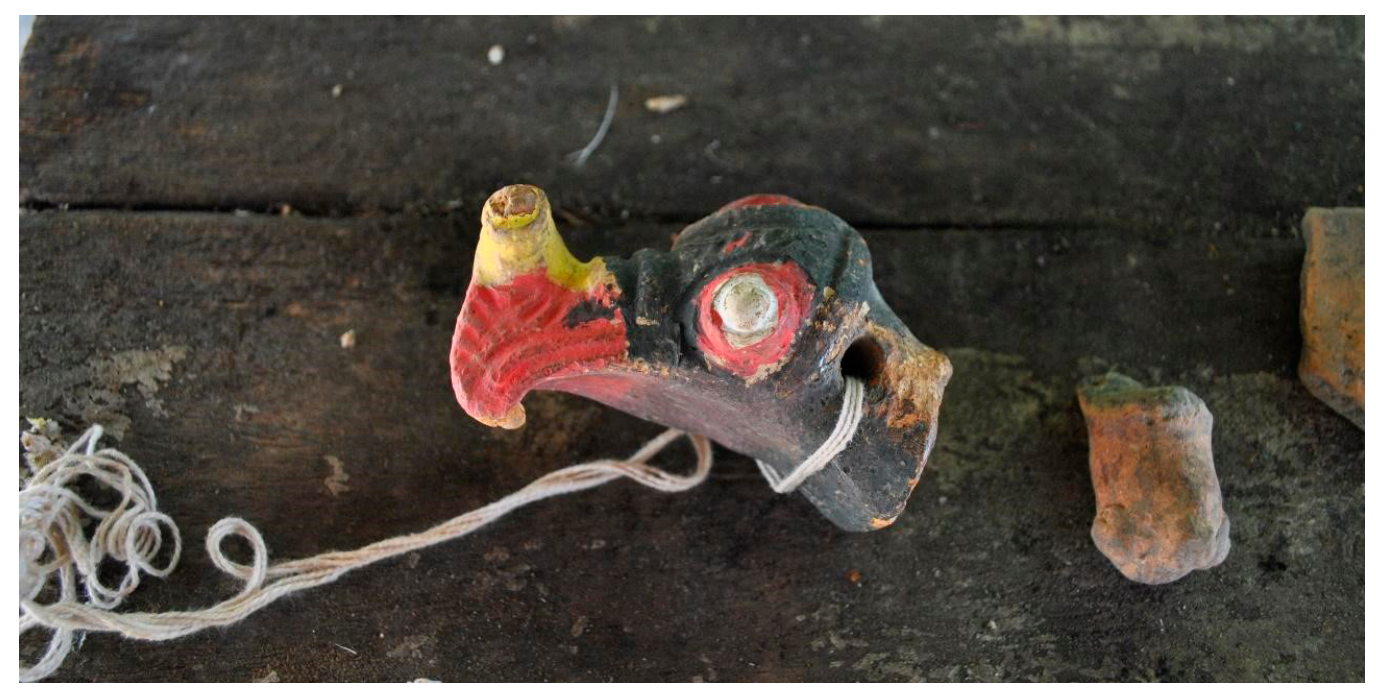

Fig. 9. Aplique de cabeça de urubu Konduri feito pingente de colar, parte da coleção de moradores da Aldeia Mapium. $\mathrm{O}$ aplique recebeu tintas que evocam as cores do urubu real.

Fonte: Fotografia de Camila Jácome. 
Um casal de idosos, também na aldeia Santidade, mostrou-nos outro colar com pingente Konduri. A senhora era uma hábil ceramista quando jovem e seu marido um ex-xamã. Recentemente ele se envolvera em uma tentativa de cura de meninas que apresentavam sinais de uma "possessão" pelo espírito da cobra grande. Esse breve relato, muito mais complexo do que o tratamento recebido aqui sugere, deixou evidente que seu ex-ofício não estava de fato abandonado, mesmo após tantos anos da conversão de seu povo ao cristianismo. Mas como operaria ou qual a função desse pingente/colar de cerâmica Konduri em uma relação xamânica?

Colares/amuletos eram muito utilizados antes da conversão, principalmente pelos homens. Um exemplo é o ehdoyati, colar feito com pingentes de dentes de diferentes animais, como o jaguar, a lontra e o macaco (Fock 1963: 118). O efeito dele em quem o usava era torná-lo um caçador tão ágil quanto o jaguar, tão bom pescador quanto a lontra e um coletor tão capaz quanto o macaco. A partir desse exemplo, podemos pensar que esses colares com pingente Konduri de cabeça de urubu poderiam ser uma espécie de talismã de agência xamânica. Cabe ressaltar ainda a importância do Povo Urubu (Kurumyana) na cosmologia Wai Wai (Fock 1963; Howard 2001). Eles seriam os habitantes da última camada do céu, acima de outras camadas habitadas por espíritos, e teriam aparência física muito semelhante à dos Wai Wai.

Podemos dizer que há uma materialidade/ imaterialidade do xamanismo no Trombetas, que pode ser mobilizada de alguma forma pelas peças arqueológicas. E talvez a falta de interesse da maioria das pessoas pelas cerâmicas arqueológicas se deva justamente ao potencial perigo que representam. Portanto, esse "esquecimento" ou "silenciamento" voluntário teria relação com uma situação presente, a ausência de pajés em atividade. A nova ordenação de mundo gerou novos perigos, que agora são mediados pelos pastores, bíblias, remédios e outros artefatos. Mas essa ordenação do presente expõe todos a constante perigo, pois mesmo sem pajés continua sendo possível que os espíritos retornem. Este perigo é tanto de ordem espacial, em que seres de outros lugares vêm assombrar as aldeias, mas também de ordem temporal, na qual os antigos vêm ao presente

Os dois exemplos, das paisagens históricas e arqueológicas e das cerâmicas arqueológicas e xamânicas, primeiramente, são uma tentativa não somente de relacionar e pensar o passado a partir do presente, mas também de pôr em lugares equivalentes o discurso indígena e o discurso arqueológico. Portanto, não se trata de ver, medir, ou melhor, de provar quais discursos têm ou não razão, mas de pensar a importância de ambos. Tara Million (2005), ao relatar sua experiência como arqueóloga indígena, conclui que as experiências sobre o passado, entre ocidentais e indígenas, são muito distintas, pois cada uma delas parte de princípios diversos. Os ocidentais separam natureza/espaço e cultura, e os indígenas lidam com isso de maneira combinada e sagrada. Para ela, a experiência de uma arqueologia indígena, portanto, criaria pontes de entendimentos entre princípios teóricos e práticos tão distintos. Acredito que efetivar esse tipo de prática é algo que somente pode melhorar e contribuir para uma arqueologia descolonial e que combata os estereótipos relacionados aos povos indígenas. Em uma reflexão sobre arqueologia, crítica feminista e descolonialidade Loredana Ribeiro aponta que:

Uma das questões centrais para a arqueologia brasileira atual é a necessária demolição da separação erigida entre as populações indígenas e as evidências materiais de suas histórias enquanto povos originários. O gesto de separação nega os significados nativos e expropria seus referentes, ao mesmo tempo infundindo, nas evidências arqueológicas, novos significados para uma história coletiva (“nacional”, senão "humana") construída sobre uma dicotomia que "valoriza as sociedades indígenas do passado enquanto condena sua contraparte contemporânea" (Gnecco, 2009: 16). Essa negação da existência de outros pressupostos ontológicos é a colonialidade, a tentativa de controle da existência de outros mundos (Ribeiro 2017: 224). 
Este trabalho foi afetado aos poucos: em campo, na solidão das leituras dos cadernos de campo e referências bibliográficas e nas conversas com outros pesquisadores, o que levou a um processo que chamei de arqueologia indigenamente orientada. Entendo que esse processo é diferente de uma arqueologia indígena nos termos propostos por Million (2005). É nesse sentido de procurar novas narrativas arqueológicas que vejo como a minha pesquisa foi transformada pelos Wai Wai.

\section{A trajetória na docência}

Comecei a lecionar no curso de arqueologia da Ufopa em 2015, com uma experiência muito pequena em ensino de história para ensino médio. A docência em si é um desafio, mas na Ufopa ganhou contornos mais complexos e interessantes, pois a universidade inclui uma grande diversidade de estudantes, vindos de comunidades tradicionais, ribeirinhas, quilombolas e indígenas de regiões próximas a Santarém, além daqueles que vivem no centro urbano do município.

Até 2017 ingressaram pelo Processo Seletivo Especial Indígena, em todos os cursos de graduação regularmente ofertados na Ufopa, 351 indígenas de dezoito povos (Arantes 2017; Pereira 2018). Essa diversidade cultural dos alunos indígenas se divide em três grandes grupos de estudantes na Ufopa:

1. Os alunos do baixo Tapajós, entre os quais se incluem os treze povos de aldeias dos rios Tapajós, Arapiuns e da região do planalto Santareno. São eles: Apiaká, Arapium, Arara Vermelha, Borari, Cara Preta, Jaraqui, Kumaruara, Maytapu, Munduruku, Tapajó, Tapuia, Tupaiú e Tupinambá.

2. Os alunos do médio e alto Tapajós (municípios de Itaituba e Jacareacanga), que são os Munduruku.

3. E os alunos da região de Oriximiná, da bacia do Trombetas, que incluem os Wai Wai, Katxuyna, Katuena etc.
Até o ano de 2016 os alunos indígenas da Ufopa faziam o curso regularmente, mas a partir de 2017 incluíram um ano a mais no seu percurso acadêmico, a Formação Básica Indígena, na qual acompanham disciplinas preparatórias, como português, matemática, informática, metodologia científica, entre outras. Essa foi uma das ações das políticas afirmativas mais importantes, para além das próprias cotas, e seu objetivo é auxiliar em um dos problemas frequentes que os estudantes indígenas enfrentam: o elevado índice de reprovação e desistência das disciplinas, assim como uma grande dificuldade de concluir seus cursos. Os motivos que geram essas situações são variados, desde a dificuldade linguística, despreparo pedagógico dos professores, falta de recursos financeiros para se manter na cidade, até o racismo que sofrem de colegas, professores e outros servidores da universidade.

Considerando que esse é um caminho, mas não o único, para resolver a questão da reprovação e desistência dos estudantes indígenas, pensamos enquanto grupo de professores da antropologia e arqueologia que precisávamos traçar uma estratégia mais direta e coletiva para lidar com as questões dos estudantes indígenas dos nossos cursos. Para isso, estabelecemos que alunos indígenas e quilombolas teriam disciplinas de apoio durante os oito semestres de duração do curso, denominada Laboratório de Textos Antropológicos e Arqueológicos, ligada ao curso de antropologia, e Laboratório de Textos Arqueológicos e Antropológicos, ligada ao curso de arqueologia; alternadamente ministradas por professores dos dois cursos.

Ministrei essa disciplina em 2017 para estudantes da arqueologia e antropologia de todos os contextos etnográficos mencionados acima. É a partir dessa experiência e do meu papel enquanto professora e orientadora de estudantes indígenas que faço essas ponderações sobre estes futuros arqueólogos(as) e antropólogos(as) indígenas.

Primeiramente, penso que nós da academia não indígena, majoritariamente branca, temos de considerar algumas questões. 
$\mathrm{O}$ que querem os jovens indígenas na universidade? E o que querem as comunidades e famílias desses jovens, partes fundamentais no processo de suporte aos estudantes?

É praticamente uma unanimidade entre os estudantes indígenas o desejo de saírem formados para trabalhar pelos "parentes", seja os da sua própria comunidade ou de outras. Aqueles que continuam nos centros urbanos depois de formados trabalham em atividades que envolvem questões políticas e territoriais indígenas (em ONGs e no Estado) ou estão dando continuidade à sua formação na pós-graduação. Já as comunidades e famílias veem nesses jovens potenciais profissionais, que podem tanto ajudar diretamente com o trabalho quanto na representação dos interesses coletivos no mundo não indígena. Ou seja, um estudante indígena nunca é só um estudante indigena, mas também é a representação dos interesses de sua comunidade.

Um reflexo disso se vê na escolha de seus temas de pesquisa, seja de iniciação científica ou de preparação para os trabalhos de conclusão de curso (TCC). Independentemente do povo, os temas geralmente se relacionam com questões sobre território, em especial, aqueles que estão sob litígio, e com questões voltadas à tradicionalidade de seus povos: conhecimentos, língua, práticas de saúde, manifestações culturais e rituais. Nesse último caso existe um padrão comum de estar lidando com tradições (rituais, conhecimentos etc.) em risco de extinção, pois em geral somente os mais velhos as conhecem. Dessa forma, além da preservação de conhecimentos, essas pesquisas também lidam com a reprodução e luta pela perpetuação desses conhecimentos.

Quase todos os estudantes que acompanhei diziam que suas fontes bibliográficas e teóricas eram seus avôs e avós, pais e mães, tios e tias, enfim, todas as pessoas que guardam e mantêm o conhecimento de seu povo. Essa referência é tão importante que muitas das pesquisas utilizam muito mais a bibliografia "nativa" do que a bibliografia oficial, que muitas vezes sequer toca nos temas sobre os quais esses jovens pesquisadores indígenas têm se debruçado. $\mathrm{O}$ acesso a essas fontes bibliográficas vivas também é muito diferenciado, já que os pesquisadores não são "estrangeiros", "brancos", da "cidade", mas são filhos(as), netos(as), parentes nos quais se pode confiar ao compartilhar aquele conhecimento tradicional. Dessa forma, arqueólogos(as) e antropólogos(as) indígenas têm um imenso potencial de propiciar elementos inéditos de suas próprias culturas ao público, potencial muito maior do que aquele da arqueologia e antropologia feita por acadêmicos não indígenas.

É importante ressaltar que no contexto atual de pandemia do coronavírus essas pesquisas tornarem-se ainda mais importantes, pois cada vida perdida dos velhos e velhas é uma biblioteca que desaparece. Um exemplo bem próximo está na matéria recém-publicada por Ruben Caixeta de Queiroz (2020), uma história e homenagem a Renato Poricwi Wai Wai, pai de Xamen Wai Wai.

Por outro lado, quando os estudantes indigenas encontram as "nossas" teorias e conceitos, há uma grande dificuldade nos processos de tradução, tanto para aqueles que falam apenas suas línguas maternas, quanto para os que já são falantes de português. Essa dificuldade conceitual, que ocorre com muita frequência, denota que mesmo a universidade brasileira sendo legal e politicamente aberta às cotas, sua estrutura de ensino, pedagógica e de pesquisa é pouca preparada para o devido acolhimento e desenvolvimento dos alunos indígenas. Nós, professores e professoras, não temos nenhuma preparação de prática de ensino específica para a interculturalidade. Aliás, a maioria de nós aprende a ser professor na prática. É notável também a ausência de autores indígenas como referências nos cursos universitários. Como já foi demonstrado, as mulheres são menos citadas e utilizadas nos programas de disciplinas dos cursos de arqueologia (Ribeiro et al. 2017), processo semelhante que também ocorre com os intelectuais indígenas.

A maior parte da universidade ignora a produção dos intelectuais indígenas, que é bastante ampla em termos de áreas de produção: antropologia, filosofia, história, ecologia, literatura, ciências jurídicas, 
política, direitos humanos, e agora também arqueologia. Em uma pequena lista podemos citar, Ailton Krenak (2000, 2019, 2020), David Kopenawa (2015), Gersem Baniwa (2014, 2006), Eliane Potiguara (1989, 2004), Daniel Munduruku (2017), Toninho Benites $(2015,2012)$, entre tantos outros. Isso sem mencionar a substanciosa produção de estudantes e pesquisadores indígenas em formas de TCC, dissertações e teses em várias universidades brasileiras, em especial nas áreas de educação, ciências sociais, história, geografia e saúde. Evidentemente, por motivos históricos e por causa do racismo estrutural de nossa sociedade, que reverbera na academia, a produção bibliográfica indígena ainda é pequena, principalmente a publicada em meios de reconhecimento pela academia. Mas existe um corpus literário suficiente para que possamos incorporar em nossas disciplinas e orientações. Essa é uma agenda urgente para a academia brasileira, pois se estamos formando arqueólogos e antropólogos indígenas para somente citar bibliografias não indígenas, estamos contribuindo para a não identificação desses jovens pesquisadores com conceitos e teorias próprias, perpetuando desta forma o processo de colonização do conhecimento.

Essa prática, portanto, de valorização das fontes indígenas, escrita ou oral, no ensino superior e na formação dos pesquisadores indígenas é uma obrigação de reparação que a academia deve ter com essas pessoas, como bem apontado por Loredana Ribeiro (2017: 211-212).

A urgência do desligamento das epistemologias eurocêntricas e a importância dos conhecimentos e paradigmas outros, não ocidentais, silenciados e propositalmente deturpados pela colonialidade do saber (WATTS, 2013; MIGNOLO, 2012). Essa constatação insere o embate colonial no centro da produção de conhecimento, embasando o argumento de que a descolonização do conhecimento não será nunca possível enquanto seu ponto de partida for o das categorias ocidentais de saber que negam aos sujeitos colonizados "o direito geopolítico e corpo-político de enunciação epistêmica” (COSTA 2014: 930).

Abrir a arqueologia e sua formação acadêmica para os povos indígenas vai além das cotas e políticas de ações afirmativas, pois passa também por fazermos uma autocrítica epistemológica e nos abrirmos para trabalhar outros conceitos e autores. Acredito que já seria um grande passo se estudantes indígenas pudessem ler e pensar sobre autores com os quais se identificassem diretamente. Não defendo uma negação completa de teorias e metodologias da arqueologia, pelo contrário, percebo que muitos estudantes indígenas querem aprender com muito afinco o que é e o que faz a arqueologia, seja sobre suas correntes teóricas ou sobre as técnicas utilizadas em uma escavação. Um exemplo muito bom disso é a reflexão de Tara Million (2005), já citada anteriormente, sobre como suas escolhas metodológicas de campo, análise de material e gestão do acervo escavado combinaram técnicas e conceitos da arqueologia acadêmica com práticas de uma visão circular das culturas nativas dos EUA.

Minha pesquisa de doutorado ganhou outros contornos após meu encontro com o Xamen e outros acadêmicos indígenas, e isso com certeza não reverberou somente no texto da tese, mas na forma como vejo e lido com a pesquisa e o ensino acadêmico. A ideia de paisagem histórica dos Wai Wai e da arqueologia também foi discutida por Xamen (2017) em seu trabalho de conclusão de curso, assim como a relação entre cerâmica e xamanismo. Esse encontro entre pesquisadores indígenas e não indígenas é um caminho muito interessante se feito com crítica, simetria e ética. Da mesma forma que devemos atuar eticamente com as comunidades com as quais pesquisamos, também devemos ter uma relação ética com os pesquisadores e estudantes indígenas. 


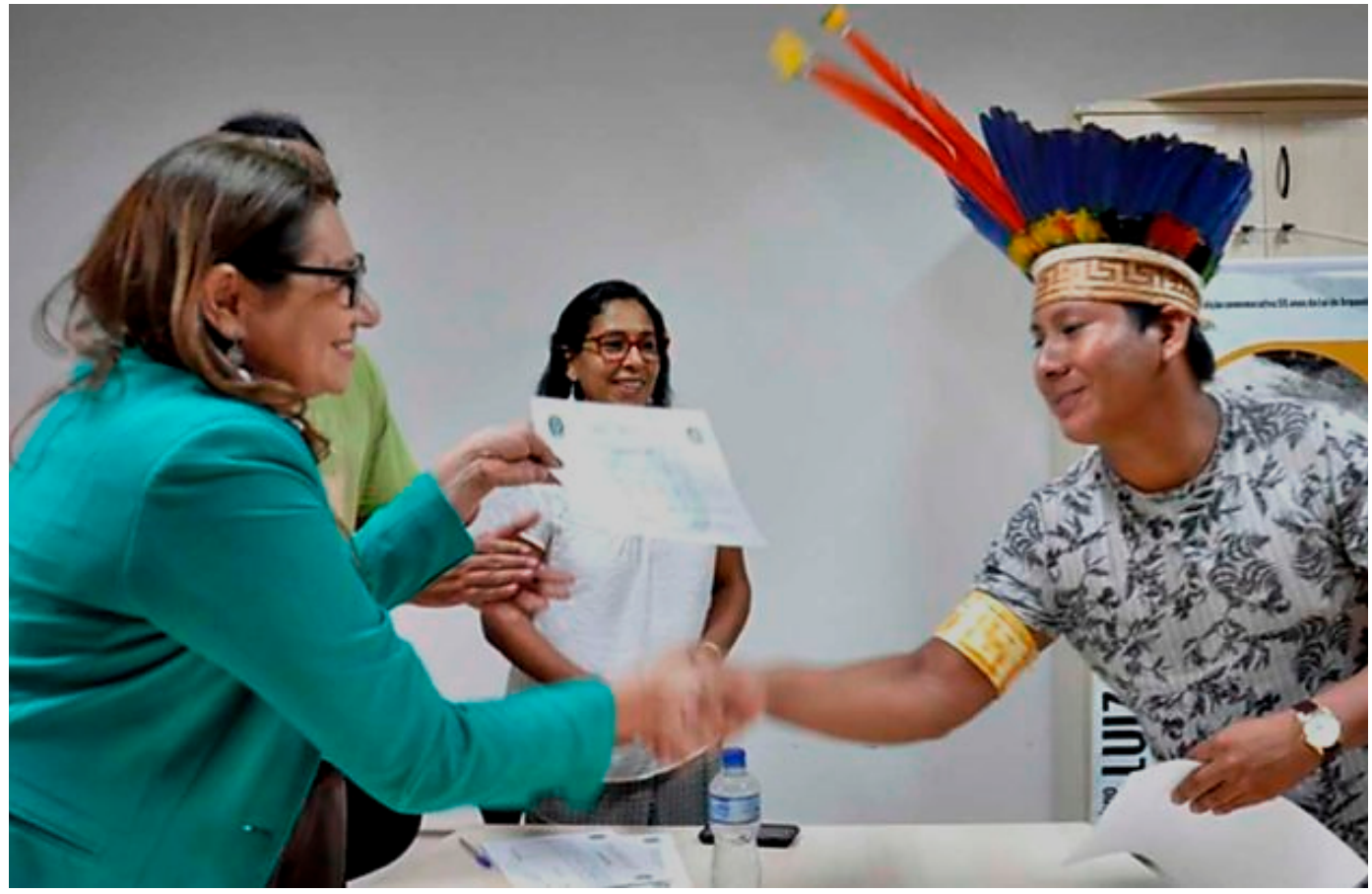

Fig. 10. Jaime Xamen Wai Wai, primeiro arqueólogo indígena formado no Brasil pela Ufopa, recebendo seu diploma das mãos da reitora Raimunda Monteiro.

Fonte: Fotografia de Camila Jácome.

\section{A “arqueologia indígena” no Brasil não é} responsabilidade exclusiva dos jovens indígenas, recém-iniciados na pesquisa arqueológica. Ao deixarmos todo o peso da construção dessa arqueologia no Brasil nas costas, mãos e mentes deles, reiteramos também um modus operandi opressivo e colonialista. Esse é um processo com o qual temos a obrigação de ser atuantes, no sentido de começarmos pela autocrítica individual e da nossa disciplina. Essa reflexão passa por esferas incômodas, mas necessárias, como o racismo, classicismo, colonialismo e desigualdade de gêneros inerentes à arqueologia. A arqueologia foi forjada e desenvolvida por parâmetros eurocêntricos, etnocêntricos, masculinistas, racistas e colonialistas. Se não assumirmos isso de forma cristalina, jamais vamos conseguir de fato superar essas bases. Para isso precisamos ouvir verdadeiramente o que os povos e estudantes indígenas nos dizem, levar a sério o que eles falam. Não se trata somente de respeitar seu conhecimento e ontologia, mas de entender que quando eles acusam o racismo não é somente uma crítica individual, mas aos regimes de conhecimento e ciências nos quais nós arqueólogas e arqueólogos não indígenas fomos formados.

Acredito que se esse processo de formação e incentivo à arqueologia indígena no Brasil não tiver nossa participação ativa e crítica, corremos o risco de fazer aquilo que Davi Kopenawa disse abertamente em uma palestra sobre indígenas na universidade na Faculdade de Educação da UFMG, em 2015. Segundo ele, a universidade estava atuando tal qual o extinto Serviço de Proteção aos Índios (SPI), atraindo os jovens para as cidades, prometendo títulos e um vida acadêmica, mas trazendo-os para uma realidade opressora e frustrante. Além disso, esses jovens estariam sendo afastados do contexto de aprendizagem contínuo que é a vida nas aldeias, às quais muitas vezes não se adaptam mais ao retornarem. Sendo assim, penso que os arqueólogos e arqueólogas indígenas mobilizam muito mais do que uma arqueologia temática e 
centrada em suas comunidades, o que por si só já é uma enorme contribuição. Mas suas pesquisas criam também uma via de discussão teórica, metodológica e de ética em pesquisa, que pode ser uma virada na disciplina arqueológica.

A arqueologia brasileira já aponta caminhos para pesquisas críticas, assim como eticamente e politicamente colocadas (Rocha et al. 2013, Rocha 2017) em relação aos povos indígenas e suas lutas. Principalmente no tocante à resistência contra grandes empreendimentos capitalistas privados e/ou do Estado brasileiro que afetam diretamente seus territórios, memórias e modos de vida tradicionais. Esse campo de luta já iniciado deveria se voltar também para a própria disciplina arqueológica, como propõe a crítica feminista.

A noção de arqueologia como estudo de objetos do passado, isolados e desligados de vozes e subjetividades do presente, nos impede de aprender com outros sujeitos e sujeitas que resistem à colonialidade do gênero. Indígenas, quilombolas, pescadoras, comunidades de periferia e outros coletivos marcados por raça, classe, sexualidade e posição na colonialidade entendem mais de comunalismo, coalizão, resistência e insurgência que cientistas e intelectuais da classe média. O hábito epistemológico moderno de apagamento das diferenças, ao qual aderimos performativamente, também nos nega subjetividade, voz e legitimidade (Ribeiro 2017: 23).

Sermos ativistas do feminismo, anticapitalismo, antirracismo, das causas indígenas, entre outras tantas batalhas, não nos torna menos acadêmicos, devido à nossa localização explícita enquanto sujeitos acadêmicos. Mas, ao contrário, expõe que a ciência e pressupostos como neutralidade científica foram forjados na modernidade e no colonialismo (Ribeiro 2017). Nesse sentido, entendo que ter um compromisso com a formação crítica de estudantes (indígenas e não indígenas), para além de ser uma luta contra a reprodução de estereótipos que geram violências epistemológicas, físicas e materiais, também faz parte do que Paulo Freire chamou de pedagogias da libertação (1970) e da autonomia (1996).

JÁCOME, C. P. Learn and teach, some reflections about indigenous archaeology. R. Museu Arq. Etn. 35: 14-35, 2020.

Abstract: Indigenous archeology is much more read and practiced in plural than in singular, both in terms of its practices and subjects, as well as its theoretical development. In this presentation I make some reflections on the plurality of this term based on two of my own research experiments. The first, a master's and doctorate project, was conducted in the region of Rio Trombetas (PA), a traditional territory of many peoples, including the Wai Wai. And the second, based on my practice as a professor of archeology and anthropology of indigenous students at the Western Pará Federal University (Ufopa).

Keywords: Indigenous archaeology; Amazon; Landscape; Ceramics; Indigenous higher education. 


\section{Referências bibliográficas}

Acuña, C. 1941. Relação do novo descobrimento do famoso Rio Grande. In: Carvajal, A.; Rojas, C. Novo descobrimento do grande rio das Amazonas. Cia Ed., São Paulo, v. 203, 53-86.

Anyon, R. 1991. Protecting the past, protecting the present: cultural resources and American Indians. In: Smith, G.S.; Ehrenhard, J.E. Protecting the past. CRC, Boca Raton, 215-222.

Arantes, L.L. 2017. Caminhos entre o território tradicional e a universidade: sobre trajetórias de mulheres indígenas e a disputa socioambiental no baixo rio Tapajós, Pará. Projeto de Qualificação de Doutorado. Universidade Federal do Oeste do Pará, Santarém.

Benites, T. 2012. A escola na ótica dos Ava Kaiowá impactos e interpretações indígenas. Contracapa, Rio de Janeiro.

Benites, T. 2015. Recuperação dos territórios tradicionais Guarani-Kaiowá. Crónica das táticas e estratégias. Journal de la Société des Américanistes 100-2: 229-240.

Bettendorf, J.F. 2010. Crônica da Missão dos Padres da Companhia de Jesus no Estado do Maranhão (1625-1698). Edições do Senado Federal, Brasília.

Boomert, A. 1981. The trauma phase of Southern Suriname. Archaeology and Anthropology 4: 105-152.

Boomert, A. 2004. Koriabo and the polychrome tradition: the Late-Prehistoric Era between the Orinoco and Amazon mouths. In: Delpuech, A.; Hofman, C. Late ceramic age societies in the eastern Caribbean monographs in American archaeology. BAR International Series 1273, Paris, 251-266.

Evans, C.; Meggers, B.J. 1955. Life among the Wai Wais. National Geography Magazine 107: 329-346.

Evans, C.; Meggers, B.J. 1960. Archaeological investigations in British Guyana. Bulletin of the Bureau of American Ethnology 177: 1-418.
Favret-Saada, J. 1990. Être affecté. Gradhiva 8: 3-10.

Favret-Saada, J. 2005. Ser afetado. Cadernos de Campo 13: 155-161.

Fock, N. 1963. Wai Wai: religion and society of an Amazonian tribe. The National Museum, Copenhagen.

Freire, P. 1996. Pedagogia da autonomia: saberes necessários à prática educativa. Paz e Terra, São Paulo.

Freire, P. 1970. Pedagogia do oprimido. Paz e Terra, São Paulo.

Frikel, P. 1958. Classificações linguístico-etnológica das tribos indígenas do Pará setentrional e zonas adjacentes. Revista de Antropologia 6: 113-189.

Frikel, P. 1970. Os Kaxuyana: notas etno-históricas: publicações avulsas. Museu Paraense Emílio Goeldi, Belém.

Gallois, D. (Org.). 2005. Redes de relações nas Guianas. Humanitas, São Paulo.

Gloria, E.L. 2017. A inconstância da forma: o sítio Poropu no contexto das Guianas. Monografia de Conclusão de Curso. Universidade Federal de Minas Gerais, Belo Horizonte.

Gnecco, C.; Ayalla, P.R. 2010. ¿Qué hacer? Elementos para una discusión. In: Gnecco, C.; Ayalla, P.R. Pueblos indígenas y arqueología en América Latina. Fundación de Investigaciones Arqueológicas Nacionales Banco de la República, Bogotá, 23-48.

Grupioni, D.F. 2009. Arte visual dos povos tiriyó e kaxuyana padrões de uma estética ameríndia. Iepé, São Paulo.

Guapindaia, V.L.C. 2008. Além da margem do rio: as ocupações Konduri e Pocó na região de Porto Trombetas, PA. Tese de Doutorado. Universidade de São Paulo, São Paulo. 
Aprender e ensinar, algumas reflexões sobre arqueologias indígenas

R. Museu Arq. Etn., 35: 14-35, 2020.

Guapindaia, V.L.C.; Lopes, D. 2011. Estudos arqueológicos na região de Porto Trombetas, PA. Revista de Arqueologia 24: 50-73.

Heriarte, M. 1874. Descripção do estado do Maranhão, Pará, Corupá e Rio das Amazonas. Carlos Gerold, Vienna.

Hilbert, P.P. 1955. A cerâmica arqueológica da região de Oriximiná. Instituto de Antropologia e Etnologia do Pará, Belém.

Hilbert, P.P.; Hilbert, K. 1980. Resultados preliminares da pesquisa arqueológica nos rios Nhamunda e Trombetas. Boletim do Museu Paraense Emílio Goeldi 75: 1-11.

Horward, C.V. 2001. Wrought identities: the Wai Wai expeditions in search of the "unseen tribes" of northern Amazonia. Tese de Doutorado. University of Chicago, Chicago.

Jácome, C.P. 2011. Pelo rio Mapuera: reflexões sobre arqueologia e etnologia indígena na Amazônia e Guiana. Dissertação de Mestrado. Universidade Federal de Minas Gerais, Belo Horizonte.

Jácome, C.P. 2017. Dos Wai Wai aos Pooco: fragmentos de história e arqueologia das gentes dos rios Mapuera (Mawtohrî), Cachorro (Katxuru) e Trombetas (Kahu). Tese de Doutorado. Universidade de São Paulo, São Paulo.

Kopenawa, D.; Albert, B. 2015. A queda do céu: palavras de um xamã yanomami. Companhia das Letras, São Paulo.

Krenak, A. 2000. O lugar onde a Terra descansa. Núcleo de Cultura Indígena, Rio de Janeiro.

Krenak, A. 2019. Ideias para adiar o fim do mundo. Companhia das Letras, São Paulo.

Krenak, A. 2020. O amanhã não está à venda. Companhia das Letras, São Paulo.

Lawson, K. 1997. Cultural interpretation in times of change. In: Nicholas, G.P.; Andrews, T. At a crossroads: archaeology and first peoples in Canada. SFU Archaeology, Brunaby, 33-52.
Luciano, G.J.S. 2006. Índio brasileiro: o que você precisa saber sobre os povos indígenas no Brasil de Hoje. MEC, Brasília.

Luciano. G.J.S. 2014. Educação para manejo do mundo: entre a escola ideal e a escola real no Alto Rio Negro. Contracapa, Rio de Janeiro.

Lucas, M.L. 2014. Entre cordas e estrelas: apontamentos sobre o tempo e o espaço hixkaryana e suas transformações. In: Anais do $11^{\circ}$ Congreso argentino de antropología social, 2014, Rosario.

Meggers, B.J. 2010. Revisiting the upper Essequibo: new perspectives on the Taruma phase. Journal of Archaeology and Anthropology 16: 1-28.

Million, T. 2005. Developing an aboriginal archaeology: receveing gifts from White Buffalo Calf Woman. In: Smith, C.; Wobst, H.M. Indigenous archaeologies: decolonizing theroy and practice. Routledge, New York, 43-55.

Munduruku, D. 2017. Mundurukando 2: sobre vivências, piolhos e afetos: roda de conversas com educadores. UK’A, Lorena.

Nimuendaju, C. 2004. The Tapajó: in pursuit of a past Amazon: archaeological researches in the Brazilian Guyana and in the Amazon region. In: Stenborg, P. Ethnological Studies, European Science Fundation, Gothenburg, 1-266.

Pereira, T.D.S.L. 2018. Os indígenas e o ensino superior na Amazônia: realidade e perspectivas da política de ação afirmativa da Universidade Federal do Oeste do Pará (2010-2015). Dissertação de Mestrado. Universidade Federal do Oeste do Pará, Santarém.

Porro, A. 2008. Notas sobre o antigo povoamento indígena do alto Trombetas e Mapuera. Boletim do Museu Paraense Emílio Goeldi 3: 387-397.

Potiguara, E. 1989. A Terra é mãe do Índio. Grumin, Rio de Janeiro.

Potiguara, E. 2004. Metade cara, Metade máscara. Grumin, Rio de Janeiro. 
Queiroz, R.C. 1999. A saga de Ewká: epidemias e evangelização entre os Wai Wai. In: Wright, R.M. Transformando os deuses: os múltiplos sentidos da conversão entre os povos indígenas no Brasil. Editora da Unicamp, Campinas, 255-284.

Queiroz, R.C. 2008. Trombetas-Mapuera: território indígena. Funai-PPTAL, Brasília.

Queiroz, R.C. 2015. Cosmologia e história Wai Wai e katxuyana: sobre os movimentos de fusão e dispersão dos povos (Yana). In: Grupioni, D.F.; Andrade, L.M.M. Entre águas bravas e mansas: indios e quilombolas em Oriximiná. Instituto de Pesquisa e Formação Indígena, São Paulo, 104-133.

Queiroz, R.C. 2020. Biblioteca da selva: Poriciwi Wai Wai, a memória de um povo e o enterro na aldeia. Piauí 168. Disponível em: <https://bit. ly/2I1Gd2W>. Acesso em: 28/09/2020.

Queiroz, R.C.; Girardi, L.G. 2012. Dispersão e concentração Indígena nas Fronteiras das Guianas: análise do caso kaxuyana. Revista Brasileira do Caribe 13: 15-42.

Ribeiro, L. 2017. Crítica feminista, arqueologia e decolonialidade: sobre resistir na ciência. Revista de Arqueologia 30: 210-234.

Ribeiro, L. et al. 2017. A saia justa da arqueologia brasileira: mulheres e feminismos em apuro bibliográfico. Estudos Feministas 25: 1093-1110.

Rocha, B.C. et al. 2013. Arqueologia pelas gentes: um manifesto. Constatações e posicionamentos críticos sobre a arqueologia brasileira em tempos de PAC. Revista de Arqueologia 26: 130-140.

Rocha, B.C. 2017. Ipi Ocemumuge: a regional archaeology of the upper Tapajós River. Tese de Doutorado. University College London, London.

Smith, C.; Burke, H. 2007. Digging it up down under: a practical guide to doing archaeology in Australia. Springer, New York.

Smith, C.; Wobst, H.M. 2005. Indigenous archaeologies: decolonizing theroy and practice. Routledge, New York.

Valentino, L. 2010. O cristianismo evangélico entre os Wai Wai: alteridade e transformações entre as décadas de 1950 e 1980. Dissertação de Mestrado. Universidade Federal do Rio de Janeiro, Rio de Janeiro.

Yde, J. 1965. Material culture of the Wai Wai. The National Museum, Copenhagen.

Wai Wai, J.X. 2017. Levantamento etnoarqueológico sobre a cerâmica Konduri e ocupação dos Wai Wai na região da Terra Indígena Trombetas Mapuera (Pará, Brasil). Trabalho de Conclusão de Curso. Universidade Federal de Oeste do Pará, Santarém.

Watkins, J. 2005. Artefacts, archaeologists, and American Indians. Public Archaeology 2-3: 187-192.

Watts-Powless, V. 2017. Lugar-pensamento indígena e agência de humanos e não humanos (a primeira mulher e a mulher céu embarcam numa turnê pelo mundo europeu! Espaço Ameríndio 11: 250-272. 